\section{Eufemisme Dalam Rubrik Konsultasi Psikologi Psyline.Id}

\author{
Dhaulika Febriana \\ Graduate Program of Linguistics \\ Universitas Gadjah Mada \\ dhaulikafebriana@gmail.com
}

\begin{abstract}
ABSTRAK
Pengujaran secara langsung dan literal dapat menimbulkan ketersinggungan hati akibat adanya penggunaan isitilah-istilah yang dinggap kasar, sehingga eufemisme digunakan untuk mengganti istilah yang dianggap kasar menjadi istilah yang lebih halus dan dapat diterima dengan baik guna mengurangi dampak negatif yang bisa ditimbulkan. Penelitian ini membahas tentang satuan ekspresi eufemisme yang terdapat dalam rubrik konsultasi psikologi PsyLine.id. Tujuan dari penelitian ini adalah untuk (1) mendeskripsikan bentuk dari eufemisme yang ada dalam rubrik konsultasi PsyLine.id, (2) menjelaskan jenis-jenis dari eufemisme yang ada dalam rubrik konsultasi PsyLine.id. Penelitian ini merupakan penelitian deskriptif kualitatif. Objek penelitian ini yaitu semua ujaran atau kalimat yang mengandung makna eufemisme yang terdapat dalam rubrik konsultasi psikologi PsyLine.id. Teknik pengumpulan data dalam penelitian ini menggunakan teknik dasar simak dan teknik lanjutan simak bebas libat cakap (SBLC) dan teknik catat.

Hasil dari penelitian ini yaitu (1) bentuk satuan ekspresi eufemisme dalam rubrik konsultasi psikologi PsyLine.id. berupa kata, frasa dan kalimat. Eufemisme yang ditemukan pada tataran kata berupa kata sederhana, kata kompleks, kata majemuk dan kata singkatan, (2) jenis satuan ekspresi eufemisme yang terdapat dalam rubrik konsultasi psikologi PsyLine.id. adalah figurative expressions atau ekspresi figuratif, circumlocutions atau sirkumlokusi, acronyms atau akronim, general-for-specific atau bentuk umum untuk khusus, understatements atau pengecilan permasalahan, learned terms or technical jargons atau pemakaian istilah teknis, dan borrowing atau pemakaian istilah pinjaman dari bahasa lain.
\end{abstract}

Kata kunci: eufemisme; PsyLine.id; bahasa Indonesia

\title{
PENDAHULUAN
}

Bahasa memiliki fasilitas untuk memperlakukan sesamanya, karena dengan bahasa penutur dapat membentuk dan menjalin hubungan yang baik dengan mitra tutur. Semua ini dapat terwujud melalui etika berbahasa yang baik. Implementasi dari etika berbahasa yang baik dapat terwujud melalui bagaimana seorang penutur memilah dan menggunakan kosakata bahasanya. Penutur sering kali menggunakan kosakata yang dianggap sopan dan halus untuk mengekspresikan perasaannya atau menyampaikan suatu informasi kepada mitra tutur. Contohnya ketika penutur ingin menyampaikan berita kepada mitra tutur mengenai kematian seseorang, maka penutur akan cenderung menggunakan istilah meninggal dunia dibanding mati, karena kata mati dianggap terlalu kasar untuk diucapkan dalam menyampaikan berita duka seseorang. Contoh lainnya adalah istilah berhubungan badan atau bersetubuh sebagai pengganti kata seks atau sanggama. Istilah ini sering digunakan seseorang dalam menyamarkan maksud sesungguhnya agar tidak terkesan vulgar. Contoh selanjutnya dalam dunia psikologis, terdapat istilah yang digunakan sebagai penghalusan dari kata gila yaitu mengalami gangguan jiwa, istilah ini digunakan sebagai bentuk kesopanan dalam berkomunikasi.

Penggunaan istilah-istilah seperti di atas sebagai suatu bentuk penghalusan ketika berkomunikasi antara penutur dan mitra tutur, dipandang sebagai suatu fenomena bahasa yang sering disebut sebagai eufemisme. Eufemisme diartikan sebagai gaya bahasa pelembut dengan cara menggantikan kata-kata dengan kata lain yang lebih sesuai dan tidak menyinggung perasaan (Kamus Bahasa Indonesia, 2008: 400).

Eufemisme dapat ditemukan dalam berbagai ragam bahasa, topik dan lini kehidupan bermasyarakat, salah satunya dalam rubrik konsultasi karena di sana orang-orang membicarakan 
perihal masalah pribadi, maka mereka cenderung akan memilah bahasanya dan menggunakan bentuk-bentuk atau istilah-istilah yang dirasa lebih halus dan sopan. Hal inilah yang memicu ketertarikan peneliti untuk meneliti lebih jauh mengenai eufemisme yang digunakan masyarakat dalam membicarakan mengenai masalah pribadi dan hubungan intim kehidupan mereka dalam rubrik konsultasi, khususnya psikologi. Rubrik konsultasi psikologi dipilih karena dalam rubrik tersebut akan dibahas secara luas mengenai masalah hidup seseorang dan tidak terbatas pada satu topik saja, sehingga akan memungkinkan peneliti untuk menemukan data-data penelitian berupa tuturan yang mengandung eufemisme yang sering digunakan masyarakat dalam berkomunikasi melalui rubrik tersebut. Rubrik konsultasi psikologi yang peneliti pilih adalah PsyLine.id. yang merupakan rubrik konsultasi psikologi online berupa website yang diampu oleh beberapa psikolog profesional dan berlisensi yang memungkinkan siapa saja dari berbagai kalangan untuk memanfaatkan jasa mereka secara gratis tanpa dipungut biaya sepeserpun. Sehingga melalui penetian ini, peneliti bertujuan untuk bisa menjelaskan mengenai bentuk dan jenis eufemisme apa yang muncul dalam rubrik konsultasi psikologi PsyLine.id..

Penelitian mengenai eufemisme sebelumnya memang telah dilakukan. Beberapa diantaranya adalah Heti Kurniawati (2011) dalam penelitiannya yang berjudul "Eufemisme dan Disfemisme dalam Spiegel Online". Hasil dari penelitian ini menujukan bahwa bentuk eufemisme dan disfemisme dalam Spiegel online ada tiga macam yaitu kata, frasa, dan kalimat. Latar belakang penggunaan eufemisme dalam Spiegel online adalah untuk 1) menghindari penggunaan kata-kata yang dapat menimbulkan kepanikan atau ketakutan, 2) tidak menyinggung, menghina atau merendahkan seseorang, 3) mengurangi atau tidak menyinggung hal-hal yang menyakitkan atau tragedi, 4) berdiplomasi atau bertujuan retoris, 5) menggantikan kata-kata yang dianggap dilarang, tabu, vulgar atau bercitra negative, 6) merahasiakan sesuatu, 7) menghormati atau menghargai orang lain, dan 8) menyindir atau mengkritik. Latar belakang penggunaan disfemisme dalam Spiegel online adalah untuk 1) menyatakan hal yang tabu, tidak senonoh, dan asusila, 2) menunjukkan rasa tidak suka atau tidak setuju terhadap seseorang atau sesuatu, 3) penggambaran yang negative tentang seseorang atau sesuatu, 4) mengungkapkan kemarahan atau kejengkelan, 5) mengumpat atau memaki, 6) menunjukkan rasa tidak hormat atau merendahkan seseorang, 7) mengolok-olok, mencela atau menghina, 8) melebih-lebihkan sesuatu, 9) menghujat atau mengkritik, dan 10) menunjukkan sesuatu hal yang bernilai rendah.

Selanjutnya penelitian dari Nita Istiasih (2016) yang membahas eufemisme dalam tesisnya yang berjudul "Eufemisme pada Tabu Seksual dalam Serial Televisi How I Met Your Mother". Hasil yang ditunjukan dari penelitian ini adalah bentuk eufemisme yang menggantikan tabu seksual dalam serial televisi How I Met Your Mother dapat berupa kata, frasa dan kalimat. Eufemisme berupa kata terdiri dari kata sederhana, kata kompleks, kata majemuk dan singkatan. Kata sederhana terdiri dari kategori nomina dan verba, kata kompleks terdiri dari kategori nomina dan adjektiva, dan kata majemuk terdiri dari kategori nomina, adjektiva dan verba. Eufemisme pada tataran frasa terdiri dari frasa nomina, frasa verba dan frasa preposisi. Referen yang ditemukan dalam penelitian ini merujuk kepada berbagai macam referen, yaitu makanan, binatang, ranjang, alat transportasi, alat elektronik, agama, waktu malam hari, permainan, nama diri, aktivitas berbaring atau tidur, keintiman dan umum. Sedangkan untuk pembentukan eufemisma yang ditemukan dalam penelitian ini ada 12 macam, yaitu ekspresi figuratif, flipansi, remodeling, sirkomlokusi, kolokial, metominia, rhyming slang, dan onomatopeia.

Eufemisme sendiri menurut para ahli adalah bentuk kebahasaan yang digunakan untuk menghindari penyebutan kata-kata atau ungkapan yang ditabukan di kalangan masyarakat tertentu (Wardaugh, 2000). Sejalan dengan itu, Keraf (2007) menyebutkan bahwa eufemisme adalah ungkapan-ungkapan yang tidak menyinggung perasaan orang, halus, dan digunakan untuk menggantikan acuan-acuan yang mungkin dirasa menghina, menyinggung perasaan orang atau mensugestikan sesuatu yang tidak menyenangkan. Pendapat lain datang dari Allan dan Burridge (1991) yang menyebutkan bahwa eufemisme digunakan sebagai alternatif untuk ungkapan yang tidak disenangi, untuk menghindari kehilangan muka, baik muka sendiri maupun yang menyinggung perasaan pendengar atau pihak ketiga. Eufemisme dapat diartikan sebagai gaya bahasa pelembut dengan cara menggantikan katakata dengan kata lain yang lebih sesuai dan tidak menyinggung perasaan (Kamus Bahasa Indonesia, 2008: 400). 
Dari berbagai pendapat di atas, dapat penliti pahami bahwa eufemisme adalah ungkapan yang lebih halus sebagai pengganti ungkapan yang dianggap kasar dan dapat menyinggung perasaan atau tabu di dalam masyarakat tertentu.

Eufemisme memiliki beragam jenis, salah satunya yang diungkapkan oleh Allan dan Burridge (1991), yaitu ada beberapa jenis yang bisa digunakan seorang penutur guna menuturkan eufemisme yaitu dengan cara:

1. Figurative expression atau ekspresi figuratif

Cara ini bersifat ibarat, kiasan atau perlambangan. Contoh: go to the happy hunting grounds 'pergi ke tanah perkuburan yang menyenangkan' $\rightarrow$ die 'mati'.

2. Flippancy atau flipansi

Flippancy yaitu memiliki makna di luar pernyataan yang ada. Contoh: kick the bucket 'menendang ember' $\rightarrow$ die 'mati'.

3. Remodelling atau pemodelan kembali

Cara ini dilakukan dengan memodelkan kembali ungkapan yang sudah ada. Contoh: sugar 'gula' $\rightarrow$ shit 'tinja'.

4. Circumlocution atau sirkumlokusi

Cara ini dilakukan dengan cara menggunakan beberapa kata yang lebih panjang dan tidak langsung. Contoh: little girl's room 'ruangan gadis kecil' $\rightarrow$ toilet 'kakus'.

5. Clipping atau kliping

Cara ini merupakan pemotongan, yaitu dengan membuat kata asli menjadi lebih singkat atau pendek. Contoh: nation 'bangsa' $\rightarrow$ damnation 'kutukan'.

6. Acronym atau akronim

Cara ini dilakukan dengan cara menyingkirkan beberapa kata agar menjadi satu kata. Contoh: snafu 'snafu' $\rightarrow$ situation normal, all fucked up 'situasi normal, semua berantakan'.

7. Abrevation atau singkatan

Cara ini dilakukan dengan menyingkat kata-kata menjadi beberapa huruf. Contoh: S.O.B 'S.O.B' $\rightarrow$ son of bitch 'anak jalang'.

8. Omission atau pelesapan

Cara ini dilakukan dengan menghilangkan sebagian ungkapan. Contoh: I need to go 'saya harus pergi' $\rightarrow$ to the lavatory 'ke WC'.

9. One for one substitution atau satu istilah menggantikan istilah lain

Cara ini dilakukan dengan menggunakan istilah yang memiliki kesamaan makna, akan tetapi lebih terkesan halus untuk menggantikan istilah yang terkesan lebih kasar. Contoh: bottom 'bawah' $\rightarrow$ ass 'pantat'.

10. General for spesific atau umum untuk khusus

Cara ini dilakukan dengan cara membuat kata yang umum menjadi khusus. Contoh: go to bed 'pergi ke tempat tidur' $\rightarrow$ fuck 'bersanggama'.

11. Part for the whole atau khusus untuk umum

Cara ini dilakukan dengan membuat kata yang khusus menjadi umum. Contoh: spend a peny'menghabiskan satu peny' $\rightarrow$ go to the lavatory 'pergi ke WC'. 
12. Hyperbole atau hiperbola

Cara ini dilakukan dengan cara melebih-lebihkan.

Contoh: flight to glory 'terbang menuju kejayaan' $\rightarrow$ death 'kematian'.

13. Understatement atau makna di luar pernyataan

Cara ini dilakukan dengan merendah atau mengecilkan. Contoh: sleep 'tidur' $\rightarrow$ die 'mati'.

14. Learned terms or technical jargons atau penggunaan istilah teknis atau jargon

Cara ini dilakukan dengan menggunakan makna yang sama, tapi berbeda bentuk, istilah secara teknis atau terminologi pada bidang tertentu. Contoh: feces 'kotoran' $\rightarrow$ shit 'tinja'.

15. Colloquial atau penggunaan istilah yang umum

Cara ini dilakukan dengan menggunakan istilah yang sering dipakai dalam kehidupan sehari-hari untuk memperhalus dan membuat sopan suatu istilah. Contoh: period 'periode' $\rightarrow$ menstruation 'menstruasi'

\section{Borrow atau penggunaan istilah pinjaman dari bahasa lain}

Cara ini dilakukan dengan cara meminjam istilah dari bahasa asing untuk mengungkapkan sesuatu agar terkesan lebih halus. Contoh: anus 'anus' $\rightarrow$ arsehole 'anus'.

Penyediaan data dalam penelitian ini menggunakan metode simak dengan teknik lanjutan simak bebas libat cakap (SBLC). Langkah-langkah yang peneliti lakukan dalam menyediakan data adalah (1) peneliti mengamati tuturan-tuturan dan pengunaan satuan lingual yang ada dalam laman PsyLine.id., (2) peneliti mencatat apa saja satuan lingual yang mengandung unsur eufemisme yang muncul dalam setiap tuturan penutur dan mitra tutur dalam laman PsyLine.id., (3) peneliti memasukkan data yang diperoleh ke dalam table atau korpus data yang selanjutnya akan dianalisa.

Metode analisis yang digunakan adalah analisis kaulitatif dengan menggunakan metode agih dan metode padan. Metode agih dengan teknik dasar bagi unsur langsung (BUL) dan metode padan dengan teknik dasar pilah unsur penentu (PUP). Langkah-langkah yang peneliti lakukan dalam menganalisa data adalah (1) Melalui tabel atau korpus data yang telah dibuat, peneliti lalu mengklasifikasian data berdasarkan bentuk, jenis dan fungsinya, (2) peneliti menjelaskan tentang bentuk eufemisme dari data yang diperoleh dalam laman PsyLine.id., (3) peneliti menjelaskan tentang jenis eufemisme yang ada dalam laman PsyLine.id..

Metode yang digunakan untuk menyajikan hasil analisis data dalam penelitian ini adalah metode informal, yaitu hasil analisis data disajikan dengan kata-kata yang menjabarkan hasil analisis data tersebut dan juga metode formal, yaitu dengan menggunakan tabel, diagram, tanda atau lambang (Sudaryanto, 2015). Setelah menganalisa data yang ada dan mendapatkan hasilnya, peneliti kemudian menjabarkan dan menyajikannya dengan menggunakan kata-kata. Peniliti juga menggunakan cetak tebal dan cetak miring sebagai penandanya. Selain itu, peneliti juga membuat tabel atau korpus data guna menyajikan hasil datanya.

\section{HASIL DAN PEMBAHASAN}

Berdasarkan penelitian yang telah dilakukan mengenai eufemisme yang terdapat dalam rubrik konsultasi psikologi PsyLine.id., peneliti menganalisa data yang ditemukan berdasarkan bentuk eufemisme dan jenis eufemisme. Berikut ini penjelasan mengenai data yang telah ditemukan.

\section{Bentuk Eufemisme dalam Rubrik Konsultasi Psikologi PsyLine.id.}

Satuan ekspresi eufemisme yang ditemukan meliputi satuan ekspresi dalam bentuk kata, frasa dan kalimat.

a. Kata

Data eufemisme berupa kata dibagi ke dalam kata sederhana (simple words), kata kompleks (complex words), kata majemuk, dan kata singkatan. 


\section{1) Kata sederhana}

Data yang ditemukan pada kata sederhana hanya berupa kategori adjektiva saja. Berikut contohnya.

(1) [...] Tapi hati saya sangat beku terhadap pria [...]. Andien, 15 April 2018.

Kata beku merupakan adjektiva karena bersifat menerangkan nomina dan digunakan untuk mengisyaratkan perasaan penutur yang sebenarnya adalah "benci". Hal ini didasarkan pada pengalaman menyedihkan penutur yaitu ditinggal pergi oleh cinta pertamanya yang lebih memilih wanita lain, sehingga penutur menjadi marah dan tidak bersahabat kepada pria. Perasaan tersebut selanjutnya mengarah pada perasaan benci dengan pria manapun yang penutur temui. Kata beku sendiri sejatinya memiliki makna padat atau keras. Sehingga penutur memilih kata ini untuk mengisyaratkan perasaan penutur.

2) Kata kompleks

Data eufemisme berupa kata kmpleks hanya ditemukan pada tataran kategori verba saja. Berikut contohnya.

(2) [...] Saya memiliki keinginan yang sulit untuk dihentikan yaitu menonton video porno dan beronani [...]. BinaSoda, 7 Maret 2018.

Kata beronani pada data (2) merupakan kata kompleks yang dihasilkan melalui proses derifasi, yaitu perubahan kelas atau kategori kata dari nomina menjadi verba, yaitu nomina 'onani' mendapatkan prefiks 'ber-' sehingga menjadi kata kerja baru 'beronani'. Beronani memiliki makna sebuah kegiatan yang dilakukan untuk mencapai kepuasan seksual dengan cara mengeluarkan cairan sperma atau air mani tanpa melakukan sanggama. Kata tersebut tergolong eufemisme karena adanya penggunaan istilah bahasa ilmiah yang digunakan untuk menyamarkan tindakan penutur yang dianggap memalukan dan tidak lazim dilakukan dan akan sangat tabu apabila diceritakan secara gamblang mengenai kegiatan yang penutur lakukan. Penutur sendiri adalah seseorang yang sudah ketagihan untuk menonton video porno semenjak dia duduk di bangku Sekolah Dasar.

3) Kata majemuk

Eufemisme berupa kata majemuk juga ditemukan dalam penelitian ini. Berikut contohnya.

(3) [...] Ibu saya suka membentak dan main tangan dengan saya [...]. MM, 8 Februari 2018.

Kata main tangan pada data (3) merupakan kata yang dihasilkan dari penggabungan kata kerja 'main' yang berarti melakukan kegiatan atau aktivitas untuk menyenangkan hati, dan kata benda 'tangan' yang merupakan anggota badan, dan apabila digabung akan memiliki arti memukul atau melukai atau melakukan kekerasan fisik terhadap seseorang. Kata tersebut tergolong eufemisme karena digunakan penutur untuk menggambarkan sikap ibunya yang kasar dan suka memukul atau melakukan kekerasan fisik terhadap dirinya, namum dalam menggambarkannya penutur menggunakan istilah lain yang tidak literal sehingga akan tersamarkan maksud asli penutur.

\section{4) Kata singkatan}

Eufemisme berupa kata singkatan juga ditemukan dalam penelitian ini. Berikut contohnya.

(4) Sodari, Ricas di Bandung, yang merasa menjadi minder dan LOLA setelah masuk kuliah. Diana Rahmawati, 5 Februari 2018.

Kata LOLA pada data (4) merupakan singkatan dari 'loadingnya lama' yang diambil dari setiap suku kata awal setiap katanya, yaitu lo- dari kata loading dan la- dari kata lama, kemudian digabungkan menjadi lola. Istilah ini memiliki makna lambar berfikir atau bodoh. Kata tersebut merupakan eufemisme karena tampak jelas adanya penyamaran maksud dari penutur dalam menggambarkan keadaan mitra tuturnya dengan menggunakan istilah yang dirasa bisa lebih diterima. 
b. Frasa

Satuan ekspresi eufemisme berupa frasa dalam penelitian ini hanya ada dua jenis, yaitu frasa nomina dan frasa verba.

1) Frasa nominal

Bentuk frasa nominal yang ditemuka dalam penelitian ini memiliki pola $\mathrm{N}+\mathrm{A}$ dan $\mathrm{N}+\mathrm{V}$. Berikut salah satu contohnya.

(5) [...] Alihkan energi liar tersebut kepada kegiatan-kegiatan positif yang menyita enerji [...]. Dra. Theresiah L Lubis, MA, 27 Maret 2018.

Frasa energi liar pada data (12) merupakan frasa nominal yang dibentuk melalui pola $\mathrm{N}+\mathrm{A}$ (nomina + adjektiva). Unsur inti dalam frasa tersebut adalah nomina 'energi' yang mendapatkan unsur permodifikasi berupa adjektiva 'liar' yang menerangkan unsur sebelumnya. Frasa energi liar digunakan untuk menggambar keadaan mitra tutur yang sedang dalam masa pubertas sehingga hormon tubuh yang berubah juga mengakibatkan adanya sesuatu baru yang muncul yaitu 'nafsu seksual atau syahwat'. Mitra tutur menceritakan bahwa dirinya sering mengalami mimpi basah dengan seorang pria di dalam mimpinya. Satuan ekspresi eufemisme tersebut digunakan oleh penutur atau psikolog sebagai bentuk halus dari 'syahwat atau nafsu seksual' dalam menjelaskan keadaan mitra tutur yang berkonsultasi, sehingga miytra tutur pun tidak akan tersinggung dengan penjelasan psikolog tersebut.

2) Frasa verbal

Frasa verbal yang ditemukan dalam penelitian ini menggunakan pola $\mathrm{V}+\mathrm{A}$. Berikut conyohnya.

(6) Dear Adisa, yang sedang merasa dipandang rendah di tempat kerja karena wanita. Zulda Meira Ara, S.Psi, 14 Maret 2018.

Frasa yang ditunjukkan oleh data (6) dipandang rendah merupakan frasa yang dibentuk dari unsur inti berupa verba pasif 'dipandang' dan unsur permodifikasi berupa adjektiva 'rendah'. Sehingga pola yang nampak adalah V + A (verba + adjektiva). Frasa dipandang rendah digunakan oleh penutur untuk menggambarkan keadaan mitra tutur yang 'diremehkan atau dianggap sepele' oleh rekan kerjanya karena dia seorang wanita merupakan salah satu bentuk ekspresi eufemisme, karena mitra tutur yang merupakan psikolog tersebut ingin menjaga perasaan penutur dengan tidak memperkeruh keadaan hatinya dengan menggunakan istilah-istilah yang kurang halus dan kurang tepat.

\section{c. Kalimat}

Eufemisme berupa kalimat juga ditemukan dalam penelitian ini. Berikut contohnya.

(7) [...] Tetapi dari semua kepala sekolah saya merasa sulit mendapatkan kecocokan [...]. Rara, 4 April 2018.

Pada data (8) saya merasa sulit mendapatkan kecocokan jelas bahwa data tersebut adalah data berupa kalimat yang terdiri dari S, P dan K. Pada kalimat yang penutur utarakan kepada psikolog, ada yang makna disamarkan dalam kalimat tersebut. Adanya penyamaran maksud, menunjukkan adanya intensi penutur untuk memperhalus bahasa yang digunakan. Makna sesungguhnya dari kalimat tersebut adalah bahwa penutur 'tidak suka' dengan kepala sekolah yang sempat menjabat di kantor, karena adanya perbedaan pandangan, sehingga sering kali menimbulkan adu pendapat.

\section{Jenis Eufemisme dalam Rubrik Konsultasi Psikologi PsyLine.id.}

Tidak semua jenis eufemisme ditemukan dalam penelitian ini, hanya beberapa jenis eufemisme saja yang muncul. Berikut ini jenis eufemisme yang ditemukan dalam penelitian ini.

\section{a. Ekspresi figurativ}

Data berupa ekspresi figurativ atau figurative expressions atau kiasan, perumpamaan, perbandingan dan lain sebagainya berhasil peneliti temukan dalam penelitian ini. Berikut contohnya. 
(8) [...] Lakukanlah berbagai aktivitas positif yang dapat membantu lbu untuk mengatasi emosi yang meledak. Cynthia Rezeki, S.Psi, 9 April 2018.

Penggunaan istilah kiasan dapat dilihat pada data (9) emosi yang meledak. Kata meledak biasanya digunakan untuk menggambarkan keadaan suatu benda yang di dalamnya terkandung zat kimia dan apabila terkena panas akan aktif dan bereaksi, sehingga akan terjadi sebuah ledakan yang tentu saja akan berbahaya bagi mahluk di sekitarnya. Benda tersebut misalnya bom, petasan, dan lain sebagainya. Penggunaan kata meledak digunakan untuk menggambarkan emosi seseorang dalam data (9), hal ini terjadi karena emosi seseorang tersebut sudah berada dipuncak dan sudah tertahankan lagi sehingga terluapkan dan diibaratkan dengan meledak. Keadaan tersebut sebenarnya digunakan untuk memperhalus istilah 'berang' karena agar lebih menggambarkan keadaan mitratutur dengan cara yang terdengar lebih sopan, maka penutur menggunakan kiasan tersebut. Kata 'berang' sendiri merupakan keadaan ketika seseorang sudah tidak bisa lagi menahan kemarahannya karena suatu hal, sehingga apabila tidak terkontrol dan terluapkan begitu saja, tentu akan membahayakan orang lain. Oleh karena itu, eufemisme emosi yang meledak dapat disejajarkan dengan kata 'berang' karena pada dasarnya memiliki sifat yang sama, yaitu tak tertahankan dan berbahaya apabila terluapkan.

\section{b. Sirkumlokusi}

Data berupa sirkumlokusi atau pemanjangan istilah atau circumlocution juga ditemukan dalam penelitian ini. Berikut contohnya.

(9) [...] Berikutnya, masalah kedua adalah menutupi status hubungan kalian pada orangtuanya. Ariny Oktaviany, S.Psi M.Psi, 2 November 2017.

Penggunaan eufemisme berupa sirkumlokusi dapat dilihat pada data (10) menutupi status hubungan kalian pada orangtuanya. Apabila kalimat tersebut dilihat tanpa konteks tentu saja tidak terlihat ada eufemisme di dalamnya, tapi apabila dilihat dan dikaitkan dengan konteks tentu akan bermakna berbeda. Eufemisme pada data (10) merupakan eufemisme yang masuk ke dalam jenis sirkumlokusi, karena cara pengungkapannya yang memanjangkan kalimat dari maksud yang sebenarnya ingin diungkapkan. Eufemisme menutupi status hubungan kalian pada orangtuanya adalah pemanjangan dari 'membohongi atau menipu orangtuanya' karena penutur ingin menggambarkan keadaan pelaku yang tidak mau jujur dan tidak mau memperlihatkan atau mengakui hubungan yang sedang dijalin kepada orang tua pasangannya, jadi mereka mencoba untuk menipu orang tua pasangannya dengan cara tetap menjalin hubungan dan tidak memberitahukan status hubungan mereka dengan cara yang lebih halus yaitu menggunakan istilah menutupi.

\section{c. Akronim}

Data eufemisme berupa akronim peneliti temukan dalam penelitian ini. Berikut contohnya.

(10) Apa yang harus saya lakukan agar bisa berhenti cemas dan was-was dan galau karena suami keren takut diincar PELAKOR?. Vita, 18 Maret 2018.

Penggunaan eufemisme berupa akronim atau singkatan dapat dilihat pada data (11) PELAKOR yang merupakan singkatan 'perebut laki orang'. Istilah ini termasuk dalam jenis akronim karena melalui proses penyingkatan dalam pembentukannya. Eufemisme ini dibentuk dari pengambilan suku kata dari setiap kata yang ada sehingga terbentuk satu kata baru. Eufemisme PELAKOR dibentuk dari pengambilan suku kata pe-dari kata perebut, lalu suku kata la- dari kata laki, dan suku kata 0 - yang ditambah $r$ dari kata orang. PELAKOR sendiri memiliki arti yaitu wanita yang merusak hubungan orang lain dengan cara merebut pasangan laki-laki dari wanita lain. Akronim ini termasuk eufemisme karena digunakan untuk menyamarkan maksud penutur dalam menggambarkan secara harfiah dan langsung sifat atau sikap seseorang yang dia takuti.

\section{d. Umum untuk khusus}

Jenis eufemisme umum untuk khusus atau general for specific juga peneliti temukan dalam penelitian ini. Berikut contohnya.

(11) Akhir-akhir ini saya mulai mengalami mimpi basah. MDN, 27 Maret 2018. 
Penggunaan eufemisme mimpi basah tergolong pada jenis umum untuk khusus, karena menggunakan istilah yang sangat umum digunakan akan tetapi memiliki makna khusus atau spesifik yang tersembunyi di dalamnya guna memperhalus penggambaran suatu keadaan. Istilah mimpi basah sangat umum digunakan orang-orang, akan tetapi istilah tersebut memiliki makna yang tidak bisa diinterpretasikan secara literal. Mimpi basah apabila ditafsirkan secara literal berarti mimpi yang basah, tapi ada ruang kosong dalam istilah tersebut yang harus dimaknai lebih dari pada yang tersurat. Penggunaan istilah umum mimpi basah memiliki arti khusus yaitu mimpi melakukan kegiatan seksual sehingga terjadi pengeluaran air mani saat tidur, dan tentu saja akan sangat tabu apabila kegiatan tersebut dijelaskan secara langsung, literal dan apa adanya tanpa menggunakan istilah tersebut.

\section{e. Pengecilan permasalahan}

Data eufemisme berupa pengecilan permasalahan atau understatement juga peneliti temukan dalam penelitian ini. Berikut contohnya.

(12) Saya memiliki pasangan, kami sudah menjalani hidup bersama selama 5 tahun trekahir. Cantika, 2 November 2017.

Data tersebut digolongkan dalam jenis eufemisme understatement karena makna yang tersembunyi dibalik menjalani hidup bersama lebih dari apa yang tersurat. Istilah menjalani hidup bersama tidak hanya sekedar hidup bersama seperti makan bersama, membaca buku bersama atau membersihkan rumah bersama, tapi tentu saja lebih dari. Orang tersebut dengan pasangannya menjalani hidup selayaknya suami istri yang sudah syah dan melakukan hal-hal sebagaimana kebutuhan pasangan yang berumahtangga untuk meneruskan generasi mereka. Mereka melakukan hubungan seksual sebelum mengikat janji suci yang syah di antara kedua belah pihak. Hal demikian sering disebut dengan 'kumpulkebo' dan istilah menjalani hidup bersama di sini bisa disejajarkan dengan 'tinggal serumah tanpa ikatan perkawinan'. Eufemisme tersebut digunakan hanya untuk menutupi realitas yg seseorang jalani dibalik istilah menjalani hidup bersama yaitu 'kumpul kebo'.

\section{f. Istilah teknis}

Eufemisme berupa istilah teknis atau learned terms or technical jargons juga ditemukan dalam penelitian ini. Berikut contohnya.

(13) Semenjak ada gosip bahwa saya adalah seorang psikopat, semua orang menjauhiku. Yunggrl, 3 Februari 2018.

Data ini digolongkan ke dalam jenis eufemisme dengan menggunakan istilah teknis karena istilah tersebut merupakan istilah ilmiah dalam dunia psikologi. Psikopat sendiri merupakan penyakit kelainan jiwa yang membuat seseorang menjadi tidak memiliki hati nurani atau empati, biasanya penderitanya bersifat manipulatif dan sering berbuat kriminal. Eufemisme ini digunakan guna memperhalus dan menyembunyikan maksud asli dari istilah tersebut. Kata psikopat digunakan karena untuk memperhalus dan menyembunyikan keadaan seseorang tanpa menjelaskannya secara gamblang apa yang dia alami, karena psikopat adalah masalah kejiwaan yang serius, sehingga penggunaan istilah teknis bisa lebih menyamarkan maksud sebenarnya dari penutur untuk menggambarkan keadaan yang dialami seseorang secara langsung dan spesifik.

\section{g. Peminjaman istilah dari bahasa lain}

Eufemisme jenis ini disebut juga sebagai borrowing. Peneliti menemukan eufemisme jenis ini dalam penelitian yang telah dilakukan. Berikut contohnya.

(14) Saya remaja 16 tahun yang sering melakukan selfharm. Yunggrl, 3 Februari 2018.

Kata selfharm berasal dari bahasa Inggris yang apabila diartikan memiliki makna 'menyakiti atau melukai diri sendiri'. Selfharm dapat tergolong dalampenyakit kejiwaan karena biasanya untuk mengekspresikan perasaan seseorang yang berupa kesedihan yang mendalam maupun kekecewaan, orang tersebut akan melukai dirinya sendiri secara sadar maupun tidak sadar. Beberapa juga melakukan hal tersebut karena merasa puas setelah melukai atau menyakiti dirinya sendiri. Sehingga penggunaan istilah selfharm di sini merupakan suatu bentuk eufemisme dalam jenis peminjaman dari 
bahasa lain, karena apabila kondisi tersebut dijelaskan dalam bahasa Indonesia maka akan terasa tabu, oleh karena itu penutur menyamarkan dan menghaluskan perilaku tersebut dengan menggambarkannya dengan menggunakan istilah dari bahasa asing.

\section{KESIMPULAN}

Berdasarkan analisis bentuk dan jenis eufemisme yang terdapat dalam rubrik konsulasi psikologi PsyLine.id., peneliti dapat menarik kesimpulan bahwa:

1. Pada rubrik konsultasi psikologi PsyLine.id. ditemukan bentuk-bentuk eufemisme berupa kata (yang berupa kata sederhana, kata kompleks, kata majemuk dan kata singkatan), frasa dan kalimat.

2. Jenis-jenis eufemisme yang ditemukan dalam rubrik konsultasi psikologi PsyLine.id. hanya tujuh jenis, yaitu ekspresi figuratif, sirkumlokusi akronim, umum untuk khusus, pengecilan permasalahan, istilah teknis dan peminjaman istilah dari bahasa lain.

3. Eufemisme memiliki tugas, yaitu untuk menyamarkan maksud sejati dari penutur dan mengungkapkan maksud yang dirasa kasar menjadi lebih halus dan lebih dapat diterima tanpa mengurangi maksud yang penutur ingin sampaikan dan tujuan yang ingin penutur capai lewat bahasa yang penutur gunakan.

\section{DAFTAR PUSTAKA}

Allan, Keith dan Kate Burridge. 1991. Euphemism and Dysphemism: Language Used as A Shield and Weapon. New York: Oxford University Press, Inc.

Istiasih, Nita. 2016. Eufemisme pada Tabu Seksual dalam Serial Televisi How I Met Your Mother. (Tesis Fakultas Ilmu Budaya Universitas Gadjah Mada). Yogyakarta. Tidak diterbitkan.

Keraf, Gorys. 2007. Diksi dan Gaya Bahasa. Jakarta: Gramedia Pustaka Utama

Kurniawati, Heti. 2011. Eufemisme dan Disfemisme dalam Spiegel Online. Yogyakarta: LITERA, Volume 10, Nomer 1, April 2011.

Pusat Bahasa. 2008. Kamus Bahasa Indonesia. Jakarta: Pusat Bahasa.

Sudaryanto. 2015. Metode dan Aneka Teknik Analisis Bahasa. Yogyakarta: Sanata Dharma University Press.

Wardaugh, Ronald. 2002. An Intoduction to Sociolinguistics. Massachusetts: Blockwell Publishers Inc. 